\title{
Immunological Consequences of Methamphetamine Protein Glycation
}

\author{
Tobin J. Dickerson, Noboru Yamamoto, Diana I. Ruiz, \& Kim D. Janda*
}

Department of Chemistry and The Skaggs Institute for Chemical Biology, The Scripps Research Institute, 10550 North Torrey Pines Road, La Jolla, California 92037

kdjanda@scripps.edu

Phone: 858-784-2516 Fax: 858-784-2595 
General Methods. Unless otherwise stated, all reactions were performed under an inert atmosphere with dry reagents and solvents and flame-dried glassware. Analytical thin-layer chromatography (TLC) was performed using $0.25 \mathrm{~mm}$ pre-coated silica gel Kieselgel 60 F254 plates. Visualization of the chromatogram was by UV absorbance, iodine, dinitrophenylhydrazine, ceric ammonium molybdate, ninhydrin or potassium permanganate as appropriate. ${ }^{1} \mathrm{H}$ NMR \& ${ }^{13} \mathrm{C}$ NMR spectra were recorded on a Varian INOVA-400 spectrometer at $400 \mathrm{MHz}$ and $100 \mathrm{MHz}$, respectively. Matrix-assisted laser desorption/ionization (MALDI) FTMS experiments were performed on an IonSpec FTMS mass spectrometer. Electrospray ionization (ESI) mass spectrometry experiments were performed on an API 100 Perkin Elmer SCIEX single quadrupole mass spectrometer. LC-ESI mass spectrometry experiments are performed on an HP 1100 MSD single quadrupole mass spectrometer. Electrospray samples are typically introduced into the mass analyzer at a rate of 100 to $1000 \mathrm{~mL} /$ minute. The declustering potential was maintained between 100 and $300 \mathrm{~V}$ to control the collisional energy of the ions entering the mass analyzer and the emitter voltage was typically maintained at $4000 \mathrm{~V}$.

Methamphetamine-derived Amadori Product (Scheme 1). D-Fructose (3.6 g, $20 \mathrm{mmol}$ ) was dissolved in acetone $(70 \mathrm{~mL})$ and concentrated $\mathrm{H}_{2} \mathrm{SO}_{4}(3.5 \mathrm{~mL})$ was added. The reaction was stirred for 90 minutes, and then cooled to $0{ }^{\circ} \mathrm{C}$. Ice-cold $\mathrm{NaOH}\left(11 \mathrm{~g}\right.$ in $\left.50 \mathrm{~mL} \mathrm{H}_{2} \mathrm{O}\right)$ was then gradually added with stirring. The solution was then concentrated, and extracted with $\mathrm{CH}_{2} \mathrm{Cl}_{2}(3 \times 20 \mathrm{~mL})$. The combined organic layers were then washed with water $(2 \times 10 \mathrm{~mL})$, dried on $\mathrm{Na}_{2} \mathrm{SO}_{4}$, and concentrated. The resulting crude product was dissolved in hot $\mathrm{Et}_{2} \mathrm{O}(\sim 5 \mathrm{~mL} / \mathrm{g})$ and pentane $(5 \mathrm{~mL} / \mathrm{g})$ was added to precipitate the desired bis-acetal as a white solid $(2.22 \mathrm{~g}, 43 \%)$.

2,6-Di-tert-butyl-4-methyl-pyridine (452 mg, $2.12 \mathrm{mmol})$ was dissolved in $\mathrm{CH}_{2} \mathrm{Cl}_{2}(10 \mathrm{~mL})$ and cooled to $-10{ }^{\circ} \mathrm{C}$. To this solution, triflic anhydride $(324 \mathrm{~mL}, 1.92 \mathrm{mmol})$ was added. Bis-acetal $(250 \mathrm{mg}, 0.96$ mmol) was dissolved in $\mathrm{CH}_{2} \mathrm{Cl}_{2}(5 \mathrm{~mL})$ and added to the reaction. The reaction was stirred 40 minutes, and then quenched with water. The solution was then extracted with $\mathrm{CH}_{2} \mathrm{Cl}_{2}(2 \times 5 \mathrm{~mL})$, dried on $\mathrm{MgSO}_{4}$, and concentrated. The crude product was then purified on silica with ethyl acetate/hexane (3:7) as the eluent to yield the desired triflate as a yellow oil (414 mg, 100\% yield).

Triflate (169 mg, $0.43 \mathrm{mmol})$ was dissolved in anhydrous DMF (2 mL) and (+)-methamphetamine, prepared from the corresponding $\mathrm{HCl}$ salt by extraction with $\mathrm{Et}_{2} \mathrm{O} /$ saturated aq. $\mathrm{NaHCO}_{3}$, was dissolved in DMF ( $1 \mathrm{~mL})$ and added to the reaction. The solution was heated under reflux for 1 hour, and the reaction concentrated under reduced pressure. Purification of the resulting protected Amadori rearrangement product by column chromatography (EtOAc/hexane 2:8) gave the desired product as a colorless oil (64.6 $\mathrm{mg}, 38 \%$ ).

The protected Amadori rearrangement product was dissolved in $2 \mathrm{~N} \mathrm{HCl}(10 \mathrm{~mL})$ and allowed to stir for 20 hours at room temperature in vacuo $(\sim 30 \mathrm{~mm} \mathrm{Hg})$. The reaction was then concentrated under high vacuum and the resulting residue dissolved in water $(\sim 5 \mathrm{~mL})$ and concentrated under reduced pressure. This operation was repeated two times in order to remove excess $\mathrm{HCl}$ from the reaction mixture and yielded the desired Amadori rearrangement product as an orange oil (55.4 mg, 98\%).

Scheme 2. Synthesis of the 1-derived Amadori rearrangement product. Reaction conditions: $(a)$ i. acetone, $\mathrm{H}_{2} \mathrm{SO}_{4}$ ii. $\mathrm{Tf}_{2} \mathrm{O}$, 2,4,6-tri-tert-butylpyridine, 43\%; (b) (+)-methamphetamine, DMF, $80{ }^{\circ} \mathrm{C}, 38 \%$; (c) $2 \mathrm{~N}$ $\mathrm{HCl}, 98 \%$.
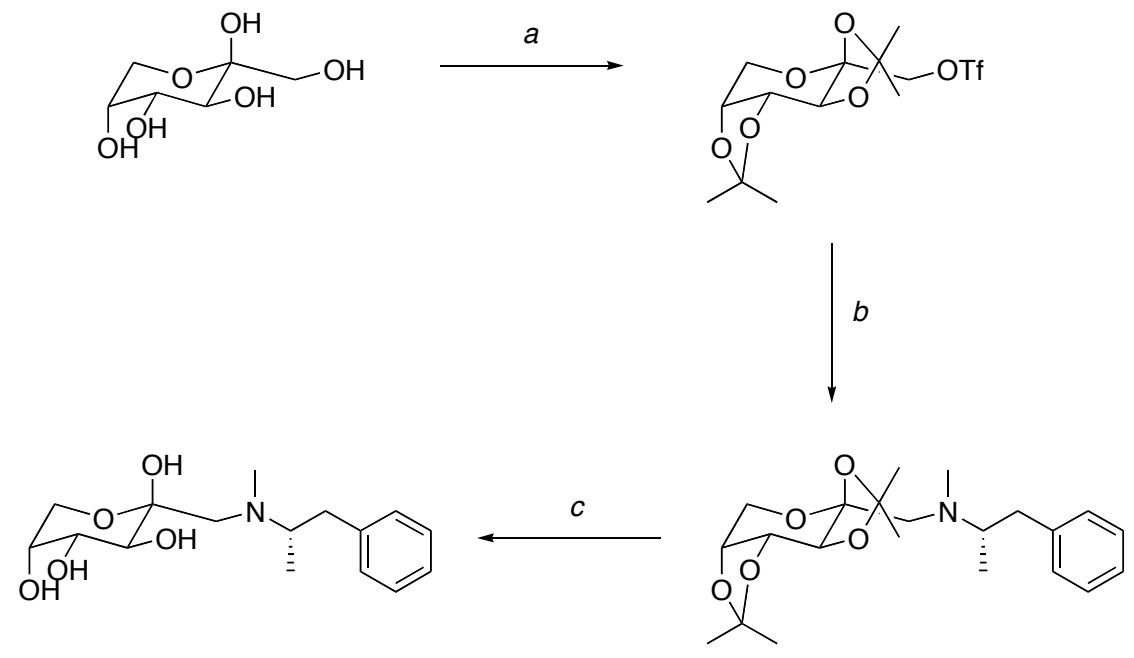
Glycation of Proteins by Methamphetamine. Glucose $(200 \mathrm{mM})$ was added to phosphate buffered saline (PBS; $200 \mathrm{mM}$; pH 7.4) to obtain a glucose-enriched buffer. The protein in question (RNase A, BSA, or MSA) was then dissolved in this buffer in a microcentrifuge tube to attain a final concentration of protein of $10 \mathrm{mg} / \mathrm{mL}$ (final reaction volume $=1 \mathrm{~mL}$ ). Immediately following the addition of protein, $(+)$ methamphetamine was added to the reaction $(0.77 \mu \mathrm{M})$ and the solution filtered through a $0.2 \mu \mathrm{M}$ syringe filter. The reactions were incubated at $37^{\circ} \mathrm{C}$ in the dark and aliquots were removed at given time intervals, diluted 1:1000 with PBS, and analyzed by ELISA using a commercially available polyclonal antibody serum (U.S. Biological). Negative control incubations were also performed using glucose and protein, and methamphetamine and protein. Neither reaction showed any binding to the polyclonal antibody serum by ELISA.

Immunization Procedures. For all immunizations, the $129 \mathrm{GIX}^{+}$mouse strain was used. Generally, four mice were used in each experiment and each injection consisted of $30 \mathrm{mg}$ of methamphetamine-AGEMSA in $100 \mathrm{~mL}$ PBS. Injections were made biweekly for a period of two weeks. One week after the last injection, blood samples were acquired by eye bleed and the serum tested by ELISA. Booster injections were performed two weeks later as a single $30 \mathrm{mg}$ dose in $100 \mathrm{~mL}$ PBS. Bleeds were again performed one week after the injection and the acquired serum tested by ELISA.

Immunochemical Detection of Methamphetamine-Modified Proteins. An ELISA plate (CoStar; 96-well) was coated overnight at $4{ }^{\circ} \mathrm{C}$ with $125 \mathrm{ng}$ protein (MSA, AGE-MSA, methamphetamine-AGEMSA, methamphetamine-AGE-RNase A, or RNase A) and then blocked with $50 \mu \mathrm{L}$ of Blotto (4\% skim milk powder in PBS) for 1 hour at $37^{\circ} \mathrm{C}$. Typically, $25 \mu \mathrm{L}$ of a 1:500 dilution of mouse serum in Blotto was then added and incubated 1 hour at $37{ }^{\circ} \mathrm{C}$. After washing, $25 \mu \mathrm{L}$ of a 1:1,000 dilution of a goat-antimouse/horseradish peroxidase conjugate in Blotto was added and incubated for 1 hour. The plate was developed with the colorimetric reagent TMB, quenched with an equal volume of $2 \mathrm{M} \mathrm{H}_{2} \mathrm{SO}_{4}$, and the absorbance measured on an ELISA plate reader at $450 \mathrm{~nm}$.

Preparation of Small Molecule Methamphetamine-AGE analog. Glucose (10 M) was added to phosphate buffered saline (PBS; $500 \mathrm{mM}$; pH 7.4) to obtain a glucose-enriched buffer. Ac-Lys-OH (19 $\mathrm{mg}, 0.1 \mathrm{mmol})$ was then dissolved in this buffer). Immediately following this, $(+)$-methamphetamine $(18.6$ $\mathrm{mg}, 0.1 \mathrm{mmol}$ ) was added to the reaction and the solution filtered through a $0.2 \mu \mathrm{M}$ syringe filter (final reaction volume $=1 \mathrm{~mL}$ ). The reactions were heated to $80{ }^{\circ} \mathrm{C}$ for 18 hours, cooled, and used without further purification in competition ELISA studies.

Competition ELISA Experiments. An ELISA plate (CoStar; 96-well) was coated overnight at $4{ }^{\circ} \mathrm{C}$ with $125 \mathrm{ng}$ protein (MSA, AGE-MSA, methamphetamine-AGE-MSA, methamphetamine-AGE-RNase A, or RNase A) and then blocked with $50 \mu \mathrm{L}$ of Blotto (4\% skim milk powder in PBS) for 1 hour at $37{ }^{\circ} \mathrm{C}$. Typically, $25 \mu \mathrm{L}$ of a 1:500 dilution of mouse serum in Blotto containing serial dilutions of competing antigen was then added and incubated 1 hour at $37^{\circ} \mathrm{C}$. After washing, $25 \mu \mathrm{L}$ of a 1:1,000 dilution of a goat-anti-mouse/horseradish peroxidase conjugate in Blotto was added and incubated for 1 hour. The plate was developed with the colorimetric reagent TMB, quenched with an equal volume of $2 \mathrm{M} \mathrm{H}_{2} \mathrm{SO}_{4}$, and the absorbance measured on an ELISA plate reader at $450 \mathrm{~nm}$.

Dot Blot Experiments. A nitrocellulose membrane was treated with drops of the appropriate protein diluted to XXX mg/mL and then blocked with Blotto $(\sim 5 \mathrm{~mL})$ at $37{ }^{\circ} \mathrm{C}$ for 30 minutes. The nitrocellulose was then treated with a XXX dilution of commercially available anti-methamphetamine polyclonal antibody (U.S. Biological) in Blotto $(\sim 5 \mathrm{~mL})$. The membrane was shaken gently for 1 hour at $37{ }^{\circ} \mathrm{C}$, and then washed with PBS $(3 \mathrm{x})$. After washing, a 1:1,000 dilution of goat-anti-mouse/horseradish peroxidase conjugate in Blotto $(\sim 5 \mathrm{~mL})$ was added and incubated at $37{ }^{\circ} \mathrm{C}$ for an additional hour. The dot blot was then developed using a XXXX TMB reagent for $\mathrm{X}$ minutes. 